\title{
PRE-PUBIC TENDON RUPTURE IN EWE
}

\author{
Gabriel Augusto Monteiro ${ }^{1}$ \\ Fernanda Saules Ignacio ${ }^{1}$ \\ Rosiára Rosária Dias Maziero ${ }^{1}$ \\ Carmo Emanuel Almeida Biscarde ${ }^{1}$ \\ Maria Clara Costa Mattos ${ }^{1}$ \\ Patrícia Alves Dutra ${ }^{1}$ \\ Sony Dimas Bicudo ${ }^{2}$
}

\begin{abstract}
Pre-pubic tendon rupture is an often affection in mares, rarer in ewes and cows because of an additional connection of the pre-pubic tendon found in these species. Etiology of this affection is not completed elucidated, but it is associated with many gestation affections. Treatment is usually unsatisfactory. This report aims to describe principle clinical and anatomopathologyc findings in an ewe at the fifth month of gestation with pre-pubic tendon rupture. Bad general clinical status led to euthanasia. Clinical and anatomopathological findings are consistent with pre-pubic tendon rupture. The report of this case works as an alert to the possibility of the occurrence of this affection in ewes and demonstrate a necessity to the parturition assistance of these animals.
\end{abstract}

Key words: dystocia, gestation, sheep

\section{RUPTURA DO TENDÃO PRÉ-PÚBICO EM OVELHA}

\section{RESUMO}

A ruptura do tendão pré-púbico é uma afecção frequente em éguas, rara em ovelhas e vacas devido a ligação adicional do tendão pré-púbico encontrado nestas espécies. A etiologia desta afecção não está elucidada, mas está associada a muitas aspectos da gestação. O tratamento é geralmente insatisfatório. O objetivo desta nota é descrever os principais achados clínicos e anatomopatológicos de uma ovelha no quinto mês de gestação com ruptura do tendão prépúbico. O mau estado clínico geral levou à eutanásia. Os achados clínicos e anatomopatológicos são consistentes com a ruptura do tendão pré-púbico. Esta nota funciona como alerta para a possibilidade da ocorrência desta patologia em ovelhas e demonstrar uma necessidade de assistência para o parto desses animais

Palavras-chave: distocia, gestação, ovelha

\section{ROMPER TENDÓN PRE-PÚBICO EN OVEJAS}

\section{RESUMEN}

La ruptura del tendón pre-púbico es una afección frecuente en yeguas, rara en ovejas y vacas debido a una conexión adicional del tendón prepúbico encontrado en estas especies. La etiología de esta afección no ha sido completamente elucidada, aunque está asociada con muchas afecciones de la gestación. El tratamiento es usualmente insatisfactorio. Este reporte

\footnotetext{
${ }^{1}$ Departamento de Reprodução Animal, Universidade Estadual Paulista -FMVZ/UNESP-Botucatu Contato principal para correspondência.

2 Docente do Departamento de Reprodução Animal, FMVZ/UNESP-Botucatu
} 
tiene como objetivo describir los hallazgos clínicos y anatomopatológicos en una oveja en el quinto mes de gestación con ruptura del tendón pre púbico. El mal estado clínico conllevó a la eutanasia. Los hallazgos clínicos y anatomopatológicos son consistentes con la ruptura del tendón prepúbico. El reporte de este caso funciona como alerta ante la posibilidad de la ocurrencia de esta afección en ovejas y demuestra la necesidad de la asistencia al parto de estos animales.

Palabras clave: distocia, embarazo, ovejas

\section{INTRODUCTION}

Pre-pubic tendon rupture is an often affection in mares, rarer in ewes (1) and cows (2) because of an additional connection of the pre-pubic tendon found in these species $(1,3)$. In mares this condition is not related to age nor breed (1) and usually occurs during the last third of gestation, when fetus shows a fast growing rate $(1,4)$.

Pre-pubic tendon rupture is clinically characterized in mares by ventral sore edema of 8 to $12 \mathrm{~cm}$ thick $(1,5)$, abdominal pain, walking reluctance, sweating, taquicardy and taquipnea (1). Complete pre-pubic tendon rupture promotes ischiatic tuberosity elevation, lordose, mammary glands displacement (1) and bloody secretion secondary to the increased tension over the mammary gland and vascular ruptures (6). However, the etiology of this affection is not completed elucidated, but it is often associated with twinning, fetal membranes hidropsia (7), fetal gigantism, prolonged gestation (1) and trauma (8).

Diagnosis is difficult especially when it involves a partial rupture. Pre-pubic tendon rupture might also be differentiated to physiologic edema of the abdominal wall (1), hydroamnion, hydrallantois, vasculitis, neoplasis right cardiac failure and ventral abdominal hernia (9).

Treatment is usually unsatisfactory. Preventive treatment in mares with a remarkable edema of the ventral portion of abdomen and reluctant walk consists in an exercise restriction and abdominal support so that the abdominal viscera weight are transferred to the vertebral column (6).

Prognostic of pre-pubic tendon rupture is bad, as most of the mares and foals dye during parturition. If it ends well, it is possible that the mare becomes able to do light works and unable to reproduction $(1,8)$.

This report aims to describe principle clinical and anatomopathologyc findings in a ewe with pre-pubic tendon rupture correlating it to described findings in other species.

\section{CASE REPORT}

A three years old West Australian Merino ewe at the fifth month of gestation was assisted at the Veterinary Hospital of the São Paulo State University, FMVZ-UNESP, Botucatu-SP with excessive pendulous abdomen. Physical exam showed ventral edema, abdominal pain, walking reluctance, taquicardy, taquipnea, ischiatic tuberosity elevation and lordose (Figure 1). Additionally, udder was cranially displaced and with hematomas.

From gynecologic exam, mucous secretion and cervical dilatation compatible with parturition were detected. Fetus showed normal moving at abdominal palpation. After physicgynecologic exams, transabdominal ultrasound examination was done which revealed the presence of two fetus with normal development.

Based on clinical signs, general status of the animal and the proximity to birth, the ewe was kept in observation and 12 hours later it began to give birth showing abdominal and uterine contractions. With the beginning of contractions it was detected exposure of fetal 
membranes, however, even though cervical dilatation was satisfactory, abdominal contractions were denied and showing difficulties to expel the lambs making necessary the traction of both. Lambs showed posterior presentation and were born in good development status and were artificially fed because the absence of colostrum production by the ewe, probably because of the big compression made over the mammary glands before parturition. Lambs did not show any complication post-parturition and were discharged.

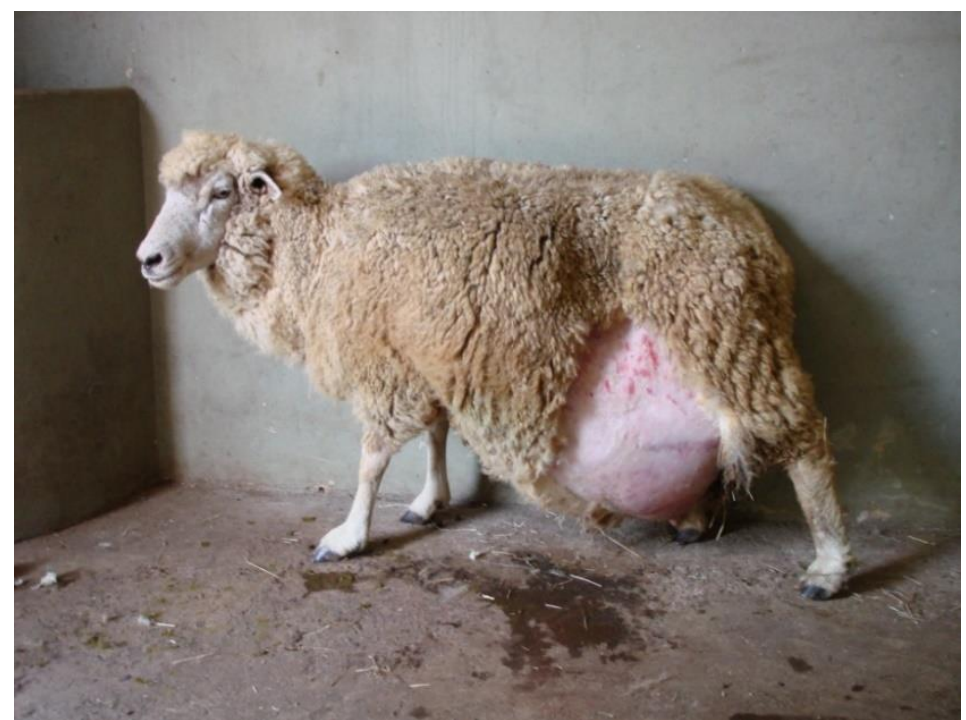

Figure 1. Ewe at the fifth month of gestation with pre-pubic tendon rupture. Large ventral distention at the place tricotomy was done for ultrasound examination.

After parturition, the ewe was apathetic, hiporexic, with placenta retention and deformation of the abdominal region. Additionally, the ewe kept with reluctance to walk and discrete lordose and as a result of the case severity, the euthanasia of the ewe was done. Anatomopathologyc findings revealed a complete rupture of the pre-pubic tendon and avulsion of the muscular abdominal wall. It was also found that mucous were pale, placenta was retained in the uterus and a discrete rhinits.

Clinical history showed consistent information of pre-pubic tendon rupture. However, definitive diagnosis is hard to be established ante morten because detected signs can be found in many other conditions $(1,9)$. Although, clinical characteristics are similar to reported in other studies $(1,5)$ in other species. Different to the horse reports $(1,10)$, fetus was insinuated trough cervical channel even though abdominal contractions were not enough for expulsion.

Prognosis was bad $(1,8)$, because the ewe had a discontinuation in the internal abdominal wall without possibilities of surgery correction. A bad general clinical status led to euthanasia three days after parturition.

Clinical and anatomopathological findings are consistent with a total pre-pubic tendon rupture, as reported by the literature (5), allowing the establishment of a definitive diagnosis for the case. Facts that determine the rupture are still unclear. The report of this case works as an alert to the possibility of the occurrence of this affection in ewes and demonstrate a necessity to the parturition assistance of these animals once the abdominal contractions are very wounded. This report also aims to emphasize the importance of differential diagnosis of this affection with other causes of distocia in ewes.

\section{REFERENCES}

1. Roberts SJ. Obstetrícia veterinária y patologia de la reproduccion (teriogenologia). 2a ed. Buenos Aires: Hemisfério Sur; 1983. 
2. Whalen RF. Rupture of the prepubic tendon in a cow. J Am Vet Med Assoc. 1956;1:50910 .

3. Hanson RR, Todhunter RJ. Herniation of the abdominal wall in the pregnancy mares. $\mathbf{J}$ Am Vet Med Assoc. 1986;189:790-3.

4. Perkins NR, Frazer GS. Reproductive emengencies in the mare. Vet Clin North Am Equine Pract. 1994;10:643-70.

5. Hendriks WK, Stout TAE, Van der Weijden GC. Spinal cord trauma in a recently foaled friesian mare as a complication of ventral abdominal rupture. Equine Vet Educ. 2007;19:247-50.

6. Mirza MH, Paccamonti D, Martin GS, Ramirez S, Pinto C. Theriogenology question of the month. Rupture of the prebubic tendon tearing of the abdominal tunic. J Am Vet Med Assoc. 1997;211:1237-8.

7. Kawcak CE, Stashak TS. Predisposing factors, diagnosis, and management of large abdominal wall defects in horses and cattle. J Am Vet Med Assoc. 1995;206:607-11.

8. Youngquist RS. Equine obstetric. In: Morrow DA. Current therapy in theriogenology. Philadelphia: WB Saunders; 1986. p.693-99.

9. Abdin-Bey MR, Ramadan RO. Retrospective study of hernias in goats. Sci J King Faisal Univ. 2001;2:77-87.

10. Jackson PGG. Rupture of the prepubic tendon in a shire mare. Vet Rec. 1982;111:38.

Recebido em:

Aceito em: 